Department, Dr. J. B. Ball. Aural Surgeon, Mr. S. Paget. Physician to Skin Department, Dr. F. G. D. Drewitt. Surgeon to Skin Department, Mr. H. F. Weiss. Surgeon in Charge of Orthopcedic Department, Mr. C. B. Keetley. Physician in Charge of Electrical Department, Dr. W. P. Ierringham. Administrators of Anasthetics, Messrs. T. Gunton, Alderton, and Rickard W. Lloyd. Secretary, Mr. R. J. Gilbert.

ST. Mark's HogptTat For Figtula a nd other Digeaghe of The Rectur, CrTy Road, E.C.-Physician, Dr. F. de Havilland Hall. Surgeons, Messrs. Allingham, and Alfred Cooper. Assistant Surgeons, Messrs. D. II. Goodsall, and F. Swinford Edwards. 322 in-patients, 2,040 out-patients. Clinical instruction is given by the Surgeons both in the out-patient department and in the department and in the wards. The practice of this hospital is free to medical men and students. Operations on Mondays and Tuesdays at 2.

ERratuM.-The name of the lady who is to deliver the Inaugural Address at the London School of Medicine for Women is Giss Walker Junbar, M.D., not "Dundas," as printed in the Student's Number of the Journat.

\section{ASSOCIÄTION INTELLIGENCE,}

\section{NOTICE OF QUARTERLY MEETING FOR 1888. ELECTION OF MEMBERS.}

Anr qualified medical practitioner, not disqualified by any by-law of the Association, who shall be recommended as eligible by any three members, may be elected a member by the Council or by any recognised Branch Council.

A meeting of the Council will be held on October 17th, 1888. Candidates for election by the Council of the Association must send in their forms of application to the General Secretary not later than twenty-one days before each meeting, namely, September 26th, and December 28th, 1888.

Candidates seeking election by a Branch Council should apply to the Secretary of the Branch. No member can be elected by a Branch Council unless his name has been inserted in the circular summoning the meeting at which he seeks election.

$$
\text { Fnancis Fowke, General Secretary. }
$$

\section{COLLECTIVE INVESTIGATION OF DISEASE.}

Reports upon the two remaining inquiries, namely, that into Drphtheria, and that into the Geographical Distribution of CBrtarn Diseases, are in preparation, and will be published as soon as ready.

The following inquiry only of the first series remains open, namely, that on the Eriology of PHTHIsis.

A fresh inquiry into the Origin and Mode of Propagation of EPIDEMics of Dipitineria has been issued.

Memoranda upon these subjects, and forms for recording observations, may be had on application to the Secretary of the Collective Investigation Committee, 429, Strand, W.C.

\section{BRANCH MEETINGS TO BE IIELD.}

\begin{abstract}
Norti of Exgtand Brancir.-The autumnal meeting will be held at MidAlesbrough on Thursday. Septembrr 20 th, at $2.45 \mathrm{r} . \mathrm{M}$. Dr. Hedley will introduce a discussion on the Recent Fpidemic of Pneumonia in the Midallesbrough District. Dr. Rutherford Morison will exhibit gall-stones removed by operation, and will rend Notes of $\Omega$ Successful Case of Removal of Bladder Tumour by Suprapubic Operation; with microscopic: specimens and drawings of the tumour. Dr. Drummond will exhilit some pathological specimens. Dr. Oliver will read a paper on Adonidine in the Treatment of Heart Discase. 1)r. Fillis will read a paper on the Treatment of Noises in the Head. Dr. Hinshelwood will read Notes on some Interesting Cases of Syphilis. The dinner after the meeting will be at 4.30 P.M.-G. E. WIIIIA MSOs, F.R.C.S. I Ionorary secretary, 22, lilion Square, Newcastic-upon-Tyne.
\end{abstract}

South-Fastern Braxch : Fast Slasex District.-A meeting of the above district will be held at the Station Hot(1. Hayward's Ileath, on Thursday, September 27th . Ur. Braid, of Burgess Hill, in the chair. Meeting at. 3.45 P.Mr. Dinner at 5.45 P.M. Charge. Bs., exclusive of wine. Dr. Talfourd Jones will give a summary of his paper on Mercury as a Diuretic, read at the last meeting. and discussion will be invited. Nembers of the Branch or others desirous o contributing papers or cames are requested to communicate at once with the Bonorary Secretary, T. J merner VERRALL, 97, Montpellier Road, Brighton.
Soutr MidensD Braxci.-The autumnal meeting of this Branch will bo held at Oundle on Tuesday, October 3 nd. Gentlemen who are desirous of bringing forward communications. etc., are requested to inform the Becretary of their intention as soon as possible. Chakliss J. KVANS, Honorary Becretary.

\section{SPECIAL CORRESPONDENCE.}

\author{
PARIS. \\ [FROY OUR OWN CORRESPONDENT.] \\ The Congress on 'Tuberculosis. \\ [Continued from page :5?.]
}

M. DE BRUN, of Beyrout, read an interesting paper on the antagonism existing between paludisin (ague or marsh fever) and tuberculosis. In Syria he had never met with tuberculosis among of persons suffering from intermittent fever, whereas among the negroes, who were exempt from this affection, tuberculosis was very frequent. M. Piot had observed similar facts in Egypt. 1I. Arloing had made several experiments with the view of discovering some means of preventing tuberculosis. So far he had $\frac{\vec{f}}{\circ}$ failed, but he still did not despair of success. Fxcision of the? glunds in relntion with the seat of inoculation was ineffectual in arresting the course of the disease. Vaccination with tuberculous 0 and ecrofulous virus did not prevent a second inoculation from $\mathrm{O}$ taking effect. M. Babès demonstrated to the Congress that in $\vec{v}$ children the bacillus of tuberculosis was nearly ulways associated $G$ with other micro-organisms, almost as injurious as "Koch's bacillus." It was necessary to realise the fact that latent encysted tuberculosis, which was extremely common among children under the form of glandular tuberculosis, could assume an acute and serious character under the influence of the associated microbes, which were often undeniable factors in the development of the disease. $\mathrm{M}$. Landouzy read a paper on paternal hereditary tuberculosis, ino which he stated that children whose mothers and wet nurses were perfectly healthy and free from any taint of tuberculosis, but whose fatliers had succumbed to the disease, might develop tubro culosis. In such cases, which are evidently examples not of tubers culous contamination but of autochthonous tuberculosis inherite from the father, it was a question of infection of the orum bp the spermatozoon. It has been observed that subsequent cono ception results in the birth of weakly marasmic children, or in repeated miscarriages.

M. Hureau de Villeneuve protested against the custom of feeding phthisical patients on raw meat and blood. Ile maintained that healthy people would run the risk of contracting tuberculosis: and, moreover, such articles of food were not suitable to the diges tive organs. M. Arloing, on behalf of M. Galtier, observed thas patients ought not to eat raw meat unless it were mutton or goat Hesh; he added that the only milk free from the taint of tube? culosis was goat s milk. M. Legroux mentioned two cases of tuber culous infection resulting from drinking unboiled milk furnished by tuberculous cows, and urged that strict sanitary measures 1 taken concerning cow's milk; the sale of ass's and goat's milk should be encouraged. M.M. Cornil and Toupet described a lesion observed in un oyster, which, morphologically, closely resembled that of tuberculosis. These pseudo-tuberculoses were very difficuly to detect. It was only by inoculations and cultivation that the could be identified.

During the Congress, several visits were paid by the members 10 the different Paris laboratories. One of the most interesting wet that to the veterinary school at Alfort. The Director, M. Nocart showed the visitors all the arrangements, and observed thity equine tuberculosis, though known to occur, was so rare that sonf authors denied it, and spoke at length on the pseudo-tulerculosis of farcy of Guadeloupe oxen, a special micro-organism which had been detected as characteristic of the bovine affection. M. Prous showed the visitors in his "Musée d' Hygiène," a model of MR Genesti and IIerscher's disinfecting stove, and said som evef transport boat, every steam packet, would be provided with orf For disinfecting rooms in which tuberculous patients had dweft M. Proust recommended sending a spray of sublimate solution $\$$ the walls. In the Paris hospitals spittoons are cleansed by boiligy water; the bacilli are surrounded by water at $90^{\circ} \mathrm{C}$. , which sufficiss to kill them. The Congress terminated with a hanquet at tho Hotel Continental, at which M. Monod, the accomplished Direchr of the Ministerial Department of the Assistance Pablique, made an excellent speech, furnishing another proof of his scientific 